\title{
Cardiac Tolerance to Ischemia in Neonatal Spontaneously Hypertensive Rats
}

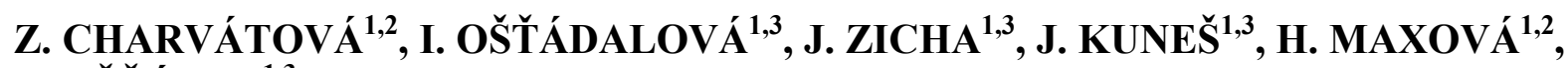 \\ B. OŠŤÁDAL ${ }^{1,3}$
}

${ }^{1}$ Centre for Cardiovascular Research, Prague, Czech Republic, ${ }^{2}$ Department of Pathophysiology, Second Faculty of Medicine, Charles University, Prague, Czech Republic, ${ }^{3}$ Institute of Physiology, Academy of Sciences of the Czech Republic, Prague, Czech Republic

Received April 2, 2012

Accepted April 25, 2012

\section{Summary}

Hypertension is the risk factor of serious cardiovascular diseases, such as ischemic heart disease and atherosclerosis. The aim of the present study was to analyze the development of cardiac tolerance to ischemia in neonatal spontaneously hypertensive rats (SHR) and possible protective effect of ischemic preconditioning (IP) or adaptation to intermittent high-altitude hypoxia (IHAH). For this purpose we used 1- and 10-day-old pups of SHR and their normotensive control Wistar Kyoto rats (WKY). Isolated hearts were perfused in the Langendorff mode with Krebs-Henseleit solution at constant pressure, temperature and rate. Cardiac tolerance to ischemia was expressed as a percentage of baseline values of developed force (DF) after global ischemia. IP was induced by three 3-min periods of global ischemia, each separated by 5 -min periods of reperfusion. IHAH was simulated in barochamber $(8 \mathrm{~h} /$ day, $5000 \mathrm{~m})$ from postnatal day 1 to 10. Cardiac tolerance to ischemia in 1-day-old SHR was higher than in WKY. In both strains tolerance decreased after birth, and the difference disappeared. The high cardiac resistance in 1- and 10-day-old SHR and WKY could not be further increased by both IP and adaptation to IHAH. It may be concluded that hearts from newborn SHR are more tolerant to ischemia/reperfusion injury as compared to age-matched WKY; cardiac resistance decreased in both strains during the first ten days, similarly as in Wistar rats.

\section{Key words}

Cardiac tolerance to ischemia - Neonatal spontaneously hypertensive rats - Conctractile function • Ischemic preconditioning $\bullet$ Chronic hypoxia

\section{Corresponding author}

Z. Charvátová, Department of Pathophysiology, Second Faculty of Medicine, Charles University in Prague, Plzeňská 221, 15000 Prague 5, Czech Republic. E-mail: zuzana.charvatova@ Ifmotol.cuni.cz

\section{Introduction}

Epidemiological studies have clearly shown that serious cardiovascular disturbances, such as atherosclerosis and ischemic heart disease, are no more diseases of the fifth and higher decades of life, but their origin and consequences may be essentially influenced by risk factors acting already during development (Fejfar et al. 1975). Some of them, including excessive food intake, increased plasma levels of cholesterol and systemic hypertension operate already in youth, whereas genetic factors are present already before the birth. It follows, therefore, that experimental studies of the responsible pathogenetic mechanisms must shift to the earlier ontogenetic periods. It has been observed that cardiac tolerance to oxygen deprivation changes significantly during the ontogenetic development: immature heart appears to be more resistant to ischemic/hypoxic injury as compared with the adult myocardium (for review see Ošt'ádal et al. 1999, 2009). The high resistance of the newborn rat heart cannot be further increased by ischemic preconditioning or adaptation to chronic hypoxia; these protective mechanisms appear only with decreasing tolerance during development (Ošt'ádalová et al. 2002).

Systemic hypertension belongs undoubtedly to the most important risk factors of ischemic heart disease in 
adults. It has been repeatedly demonstrated that the hearts from adult hypertensive rats are significantly less tolerant to acute ischemia/reperfusion injury as compared with normotensive animals (Belichard et al. 1988, Snoeckx et al. 1989, Snoeckx et al. 1993, Mill et al. 1998, Itter et al. 2004, Bešík et al. 2007). Unfortunately, the information about the immature heart is still lacking. In this connection it was of interest to raise the question whether hypertension can influence cardiac tolerance to acute oxygen deprivation also in neonatal animals. For this purpose, spontaneously hypertensive rats (SHR) were selected as a suitable model. Their similarities with the human essential hypertension include the genetic predisposition to high blood pressure (BP), increased total peripheral resistance without volume expansion, and similar responses to drug treatment (Dickhout and Lee 1998). However, the frequent use of SHR can be criticized for different reasons ranging from the heterogeneity of various breeding colonies, to inadequate use of normotensive control strains (WKY), as well as to the inappropriateness of SHR as a model of human essential hypertension (Zicha and Kuneš 1999). Nevertheless, the rational use of this hypertensive model provided a lot of valuable information: general availability of these animals allowed detailed research of cardiovascular abnormalities, their genetic background and critical periods (developmental windows) as well as possible pharmacological treatment with distinct classes of antihypertensive drugs, successfully employed in the treatment of essential hypertension. Long-term elevation of BP is highly dependent on the genotype, but it can be modified by various environmental factors such as nutrition, stress or exercise. To a certain extent, this must also be true for human essential hypertension.

The aim of the present study was to analyze (i) the development of cardiac tolerance to ischemia in SHR during the early postnatal period and (ii) the possibilities of cardioprotective effect of adaptation to chronic hypoxia or ischemic preconditioning in the immature hypertensive hearts.

\section{Methods}

All the investigations conform to the Guide for the Care and Use of Laboratory Animals published by the US National Institutes of Health (NIH publication No. 85-23, revised 1996).

\section{Animal model}

A total of 123 SHR and WKY rats at the age of
1 and 10 days of postnatal life were used throughout the experiments. Newborns were exposed together with their mothers to intermittent high-altitude hypoxia (IHAH) simulated in a hypobaric chamber (altitude of $5000 \mathrm{~m}$ above sea level, barometric pressure $405 \mathrm{~mm} \mathrm{Hg}, 54 \mathrm{kPa}$, $\left.\mathrm{P}_{\mathrm{O} 2}=85 \mathrm{~mm} \mathrm{Hg}, 11.3 \mathrm{kPa}\right) 8 \mathrm{~h} /$ day, from postnatal day 1 to 9 (a total of nine exposures). At the age of 10 days, the adapted rats were used for experiments. The 10-dayold control (normoxic) animals were kept for the corresponding period at a barometric pressure and $\mathrm{P}_{\mathrm{O} 2}$ equivalent to an altitude of $200 \mathrm{~m}$ above sea level. Experimental and control groups of were composed from at least three different litters. All mothers had free access to water and a standard laboratory diet ad libitum.

\section{Heart function}

The animals were weighed and killed by cervical dislocation. Then the hematocrit was measured by a micromethod, the chest was quickly opened and a stainless steel cannula (with an external diameter of $0.45 \mathrm{~mm}$ for day 1 and $0.8 \mathrm{~mm}$ for day 10) was inserted into the aorta. The heart was rapidly excised, the atria were removed and the ventricles were perfused in the Langendorff mode under constant pressure corresponding to the values found in vivo and to the mean arterial blood pressure for the given developmental stage (Clubb et al. 1987). The 1-day-old SHR were thus perfused under pressure of $33 \mathrm{~cm}$ of water in contrast with $25 \mathrm{~cm}$ of water in 1-day-old WKY; 10-day-old neonates of both strains were perfused under identical pressure $(73 \mathrm{~cm}$ of water). The hearts were perfused with a Krebs-Henseleit solution containing (in mmol/l): $\mathrm{NaCl} 118.0 ; \mathrm{KCl} 4.7$; $\mathrm{CaCl}_{2}$ 1.25; $\mathrm{MgSO}_{4}$ 1.2; $\mathrm{NaHCO}_{3}$ 25.0; $\mathrm{KH}_{2} \mathrm{PO}_{4}$ 1.2; glucose 7.0 and mannitol 1.1. The solution was saturated by a mixture of $95 \% \mathrm{O}_{2}$ and $5 \% \mathrm{CO}_{2}(\mathrm{pH}$ 7.4) and temperature was maintained at $37{ }^{\circ} \mathrm{C}$. The hearts were electrically stimulated at a rate of 200 beats/min using silver electrodes attached to the base of the heart. The stimulation was performed with pulses of alternating polarity, $1 \mathrm{~ms}$ duration and voltage set at $50 \%$ above the threshold level. The resting force was gradually increased by means of a micromanipulator to the level at which the developed force (DF) was approximately $80 \%$ of the maximum force reached at optimum preload. The contractile function of this isolated heart was measured using an isometric force transducer connected by a glass fiber, two-arm titanium lever and silk suture $(0.7$ metric) to the apex of the heart. The DF ( $g$ ) and $+\mathrm{dF} / \mathrm{dt} \max$ $(\mathrm{g} / \mathrm{min})$ was evaluated automatically from the force signal 
Table 1. Body weight, heart weight and hematocrit in WKY and SHR pups on day 1.

\begin{tabular}{lcccccc}
\hline Group & $\mathbf{n}$ & $\begin{array}{c}\text { Body weight } \\
\text { [g] }\end{array}$ & $\begin{array}{c}\text { Heart weight } \\
{[\mathbf{m g}]}\end{array}$ & $\begin{array}{c}\text { Heart/body weight } \\
{[\mathbf{m g} / \mathbf{g}]}\end{array}$ & $\begin{array}{c}\text { Dry solids content } \\
{[\mathbf{\%}]}\end{array}$ & $\begin{array}{c}\text { Hematocrit } \\
{[\%]}\end{array}$ \\
\hline$W K Y$ & 14 & $5.0 \pm 0.1$ & $21.2 \pm 0.7$ & $4.3 \pm 0.1$ & $18.8 \pm 0.3$ & $38.6 \pm 1.3$ \\
$S H R$ & 9 & $4.8 \pm 0.1$ & $27.6 \pm 0.9^{\text {a }}$ & $5.8 \pm 0.2^{\text {a }}$ & $16.1 \pm 0.5^{\text {a }}$ & $36.2 \pm 1.5$ \\
\hline
\end{tabular}

Data are means \pm S.E.M. Significantly different $(p<0.05):{ }^{a}$ vs. WKY.

Table 2. Body weight, heart weight and hematocrit in WKY and SHR pups on day 10.

\begin{tabular}{|c|c|c|c|c|c|c|c|c|}
\hline Group & & $\mathbf{n}$ & $\begin{array}{c}\text { Body } \\
\text { weight } \\
{[\mathrm{g}]}\end{array}$ & $\begin{array}{c}\text { Heart weight } \\
{[\mathrm{mg}]}\end{array}$ & $\begin{array}{c}\text { Heart/body } \\
\text { weight } \\
{[\mathrm{mg} / \mathrm{g}]}\end{array}$ & $\begin{array}{c}\text { Dry solids } \\
\text { content } \\
{[\%]}\end{array}$ & $\begin{array}{c}\text { RV/LV } \\
\text { ratio } \\
{[\%]}\end{array}$ & $\begin{array}{c}\text { Hematocrit } \\
{[\%]}\end{array}$ \\
\hline \multirow{2}{*}{$W K Y$} & normoxic & 13 & $18.7 \pm 0.6$ & $77.5 \pm 2.5$ & $4.2 \pm 0.1$ & $18.4 \pm 0.3$ & $31.7 \pm 0.5$ & $29.1 \pm 1.3$ \\
\hline & adapted & 18 & $14.8 \pm 0.5^{b}$ & $72.0 \pm 2.0$ & $4.9 \pm 0.1^{b}$ & $17.8 \pm 0.3$ & $38.0 \pm 0.7^{b}$ & $37.5 \pm 1.2^{b}$ \\
\hline \multirow{2}{*}{ SHR } & normoxic & 18 & $12.2 \pm 0.3^{\mathrm{a}}$ & $69.9 \pm 2.6^{\mathrm{a}}$ & $5.8 \pm 0.2^{\mathrm{a}}$ & $15.5 \pm 0.3^{\mathrm{a}}$ & $33.2 \pm 0.9$ & $23.7 \pm 0.9^{\mathrm{a}}$ \\
\hline & adapted & 16 & $8.9 \pm 0.3^{b}$ & $50.7 \pm 1.9^{b}$ & $5.7 \pm 0.1$ & $16.8 \pm 0.2^{b}$ & $36.6 \pm 0.9^{b}$ & $35.8 \pm 1.3^{b}$ \\
\hline
\end{tabular}

Data are means \pm S.E.M. Significantly different $(p<0.05):{ }^{a}$ vs. WKY, ${ }^{b}$ vs. normoxic.

using an on-line computer according to Ošt'ádalová et al. (1993, 1996, 1998, 2002).

\section{Cardiac tolerance to ischemia}

After a period of stabilization, baseline values of DF were recorded. The hearts from the experimental group of 10-day-old animals were preconditioned by subjecting them to three 3-min periods of global ischemia, each separated by a 5-min period of reperfusion. The remaining non-preconditioned 10-dayold hearts and all 1-day-old hearts were simply perfused during the corresponding period. All hearts were then exposed to $40 \mathrm{~min}$ of sustained global ischemia followed by reperfusion up to maximum recovery of DF (the last value of DF before its decay) (Cave 1996, Ošt'ádalová et al. 1998). DF was measured in all hearts in 3-min intervals during the reperfusion period. Tolerance to ischemia was expressed as a recovery of DF (percentage of baseline values). After the experiment, the hearts were weighed; in addition, 10-day-old hearts were divided into right ventricle and left ventricle with the septum; dryweight values were obtained after drying the tissue samples at $90^{\circ} \mathrm{C}$ to constant weight.

\section{Inotropic response to $\mathrm{Ca}^{2+}$}

For these experiments the hearts were perfused with a Tyrode solution containing (in mmol/l): $\mathrm{NaCl}$
145.0; $\mathrm{KCl}$ 5.9; $\mathrm{CaCl}_{2}$ 1.25; $\mathrm{MgCl}_{2}$ 1.2; glucose 11.0; mannitol 1.1, and HEPES 5.0. The $\mathrm{pH}$ was adjusted to 7.4 by Tris, and the solution was saturated with $100 \%$ $\mathrm{O}_{2}$. After stabilization, $\mathrm{Ca}^{2+}$ concentration was decreased to $0.625 \mathrm{mmol} / 1$ and thereafter gradually increased (1.25, $2.5,5.0,7.5$, and $10.0 \mathrm{mmol} / \mathrm{l})$. The maximum effect of each concentration was recorded.

\section{Statistical analysis}

The results are expressed as means \pm S.E.M. Each observation was obtained from at least eight heart preparations in each group. Differences in the recovery of contractile function among the groups were evaluated using two- and one-way analysis of variance. For preliminary analysis, three-way analysis of variance was used. For pairwise mean comparisons the StudentNewman-Keuls multiple-range test was applied. All programs used were from BMDP Statistical Software, University of California. Differences were considered statistically significant when $\mathrm{p}<0.05$.

\section{Results}

\section{Weight and contractile parameters}

Early postnatal development of the body weight, cardiac weight and cardiac functional parameters of SHR in comparison with WKY are summarized in Tables 1-3. 
Table 3. Baseline values of contractile parameters in WKY and SHR pups on day 1 and 10.

\begin{tabular}{lllccc}
\hline Group & Age & \multicolumn{1}{c}{$\begin{array}{c}\text { DF } \\
{[\mathbf{g}]}\end{array}$} & $\begin{array}{c}\text { DF/ heart weight } \\
{[\mathbf{g} / \mathbf{g}]}\end{array}$ & $\begin{array}{c}\text { DF/dry } \\
\text { solids content } \\
{[\mathbf{g} / \mathbf{g}]}\end{array}$ & $\begin{array}{c}\mathbf{d F} / \mathbf{d t ~} \mathbf{m a x} \\
{[\mathbf{g} / \mathbf{m i n}]}\end{array}$ \\
\hline \multirow{2}{*}{$W K Y$} & 1 & $1.9 \pm 0.1$ & & $305.2 \pm 15.0$ & $26.9 \pm 1.8$ \\
& 10 & $5.7 \pm 0.2$ & $55.4 \pm 3.0$ & $404.0 \pm 15.1$ & $129.2 \pm 4.4$ \\
$S H R$ & 1 & $1.1 \pm 0.1$ & $74.5 \pm 3.1$ & $256.4 \pm 14.9^{\mathrm{a}}$ & $24.1 \pm 1.2$ \\
& 10 & $4.1 \pm 0.2^{\mathrm{a}}$ & $40.8 \pm 1.8^{\mathrm{a}}$ & $387.0 \pm 20.1$ & $89.7 \pm 4.2^{\mathrm{a}}$ \\
\hline
\end{tabular}

Data are means \pm S.E.M. Significantly different $(p<0.05):{ }^{a}$ vs. WKY.

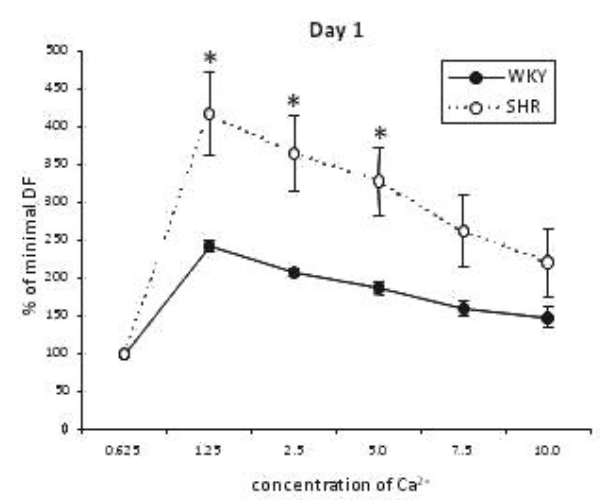

Body weight in both strains did not differ on postnatal day 1 . However, during the early postnatal development SHR pups had a significantly lower weight gain so that on day 10 the body weight of SHR pups was significantly lower as compared with WKY. Heart weight was significantly increased both in 1-day-old and 10-day-old SHR pups. On the other hand, dry solids content of hypertensive neonates was significantly decreased.

Absolute baseline values of $\mathrm{DF}$ and $\mathrm{dF} / \mathrm{dt} \max$ were the same in both strains just after birth. However, in 10-day-old SHR these contractile parameters were significantly decreased as compared with WKY. DF (expressed per $\mathrm{g}$ of dry solids content in heart) was already significantly decreased in 1-day-old SHR as compared with normotensive controls.

The exposure of neonates of both strains to IHA significantly increased hematocrit and reduced body weight; relative heart weight was increased in WKY only. On the other hand, $\mathrm{RV} / \mathrm{LV}$ ratio was significantly increased in all adapted animals.

\section{Cardiac sensitivity to calcium}

Cardiac sensitivity to the inotropic effect of increasing $\mathrm{Ca}^{2+}$ concentration significantly changed during the early postnatal development in both strains. In 1-day-old neonates DF at higher $\mathrm{Ca}^{2+}$ concentrations decreased, whereas in 10-day-old neonates DF remained unchanged. 1-day-old SHR pups were significantly more sensitive to increasing $\mathrm{Ca}^{2+}$ concentration as compared with age-matched WKY. However, there was no difference in the sensitivity to calcium between SHR and WKY on day 10 (Fig. 1).

\section{Cardiac tolerance to ischemia}

A significant decrease in cardiac tolerance to ischemia was observed in both rat strains from day 1 to 10 . The hearts from 1-day-old SHR littermates were significantly more tolerant to ischemia than hearts from WKY of the same age. On day 10 there was already no difference in cardiac tolerance between SHR and WKY (Fig. 2).

\section{Cardiac protection by IP and adaptation to IHA}

The high cardiac tolerance of the immature 1- and 10-day-old hearts of SHR and WKY to acute ischemia cannot be further increased by ischemic preconditioning or adaptation to chronic hypoxia (Fig. 3 and 4). 


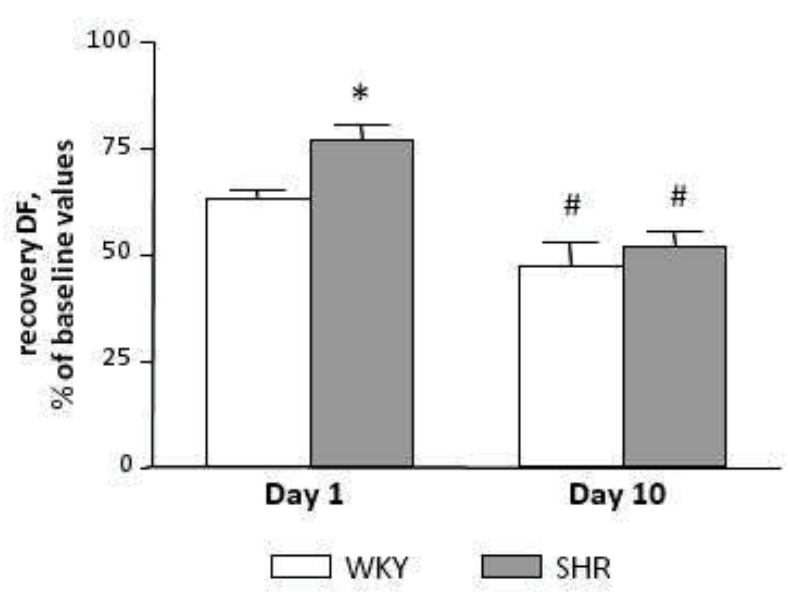

Fig. 2. Cardiac tolerance to ischemia (expressed as the recovery of DF after ischemia) in WKY and SHR. ${ }^{*}$ Significantly different $(p<0.05)$ vs. WKY of the corresponding age, \# significantly different $(p<0.05)$ vs. day 1 of the corresponding strain.

\section{Discussion}

Cardiac tolerance to ischemia changes significantly during the ontogenetic development. Riva and Hearse (1993) observed that the age-dependent changes in resistance to global ischemia in the isolated rat heart showed a biphasic pattern with increasing tolerance from the $5^{\text {th }}$ to the $23^{\text {th }}$ day of age, followed by a decline to adulthood. Detailed analysis of the tolerance of the isolated hearts of Wistar rats to global ischemia during the first week of life has, however, revealed a significant decrease of tolerance during the first postnatal week (Ošt’ádalová et al. 1998), suggesting a possible triphasic pattern of the ontogenetic development of cardiac sensitivity to ischemia. We have also observed a similar tendency in neonatal hearts of SHR and WKY: on postnatal day 1 the cardiac tolerance to ischemia was significantly increased as compared with 10-day-old animals. Moreover, 1-day-old hypertensive neonates were significantly more tolerant to ischemia as compared with age-matched control WKY; this difference disappeared during the first postnatal week. In this connection it is necessary to mention the quite opposite situation in adult animals: hypertrophied heart of adult SHR was significantly less tolerant to acute ischemia/reperfusion injury as compared with normotensive controls (Belichard et al. 1988, Snoeckx et al. 1989, 1993, Itter et al. 2004, Bešík et al. 2007).

The mechanisms of a higher resistance of the immature heart to oxygen deprivation have not yet been satisfactorily clarified (for review see Ošt’ádal et al. 2009). Moreover, the data on immature SHR are

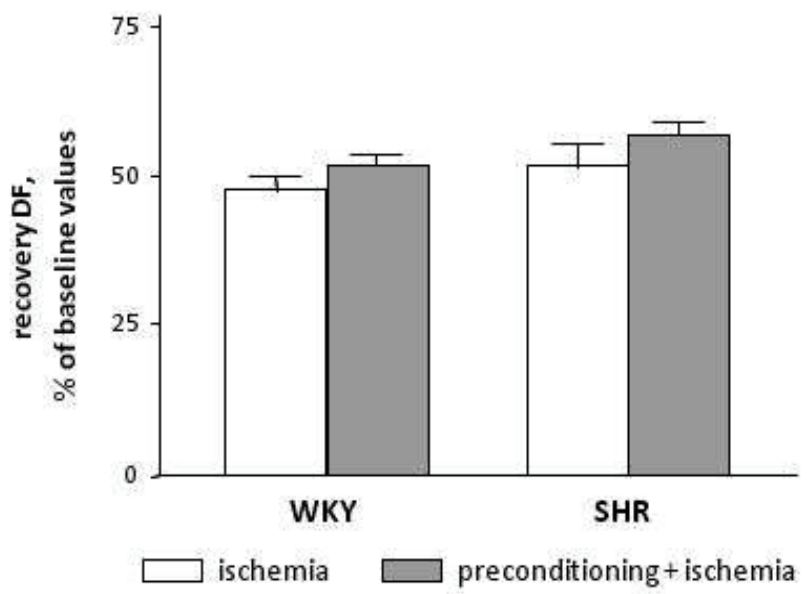

Fig. 3. Effect of ischemic preconditioning on day 10 in WKY and SHR.

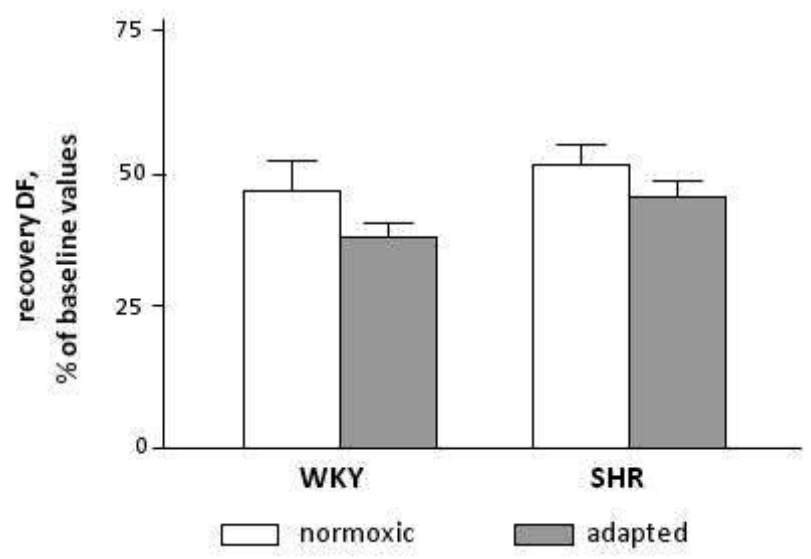

Fig. 4. Effect of adaptation to IHA on day 10 in WKY and SHR.

completely lacking. For the explanation of this fact it should be taken into consideration that mammalian fetus (and therefore also its heart) lives in the hypoxic environment, where $\mathrm{PO}_{2}$ is only $47 \mathrm{~mm} \mathrm{Hg}$, which corresponds to an altitude of $8000 \mathrm{~m}$ ("Mount Everest in utero"). The fetus is, however, well adapted: the prenatal period is characterized by polycythemia and fetal hemoglobin with the shift of the dissociation curve to the left. The major changes in oxygen saturation can be observed at the delivery. During the short period of time the fetus comes from the hypoxic environment with low $\mathrm{PO}_{2}$ and low oxygen saturation into the normal atmosphere $\left(\mathrm{PO}_{2} 160 \mathrm{~mm} \mathrm{Hg}\right.$, arterial saturation $\left.97 \%\right)$. After birth, profound adaptive changes take place in mammalian neonate, such as the onset of pulmonary circulation, the transition from fetal to neonatal circulation, the switching-on of thermoregulation and the corresponding increase in basal metabolic rate. However, under the ischemic conditions, the decline in metabolic 
rate was much slower in neonatal than in adult hearts, matching the high tolerance of newborn animals to oxygen deprivation. The paradoxical increase in ischemia tolerance despite a higher tissue metabolic rate (as compared with adults) may be at least partly explained by the ability of neonatal tissue to temporarily go back to feto-maternal metabolic level, thereby achieving a "hypoxic hypometabolism" (Mortola 2004, Singer 2004).

It may be speculated that the explanation of a higher cardiac tolerance during the early phases of postnatal ontogeny is based on the greater anaerobic glycolytic capacity, higher glycogen reserve of the immature heart (Hoerter 1976, Young et al. 1983) or amino acid utilization by transamination (Julia et al. 1990). Moreover, the immature heart is better equipped to ATP synthesis than to its breakdown and thus suffers less ischemic injury than the adult myocardium after the same ischemic insult (Southworth et al. 1997). Another factor that may contribute to the increased tolerance of the immature heart is age-related change in calcium handling (for review see Nijjar and Dhalla 1997). Developmental decrease in cardiac tolerance is probably associated with ontogenetic changes in energy metabolism, particularly in mitochondrial function. We have shown previously (Škárka et al. 2003) that the content of cytochromes in rat cardiac mitochondria increased two-fold between birth and day 30 , similarly as the expression of adenine nucleotide translocase 1. Moreover, a single population of mitochondria with relatively high mitochondrial membrane potential (MMP) was observed in newborn animals. A second population with significantly lower MMP appears at the beginning of the weaning period. Recently, we have observed significant ontogenetic differences in the role of mitochondrial permeability transition pore (MPTP) in the inner mitochondrial membrane, implicated in the molecular mechanism associated with ischemia/reperfusion injury of the adult heart (Di Lisa and Bernardi 1998, 2005). Whereas the blockade of this structure by sangliferin in the perfused rat heart had a protective effect on ischemia/reperfusion injury in the adult myocardium, it had no effect in the neonatal heart (Milerová et al. 2010). For the explanation of this difference several possibilities have to be taken into consideration: different amount of cyclophilin receptors or developmental changes in the mitochondrial content of cyclophilin $\mathrm{D}$, a protein considered to be associated with the MPTP. Furthermore, we have observed that mitochondria isolated from the neonatal heart are less sensitive to $\mathrm{Ca}^{2+}$ ions as compared with adults. These results support the hypothesis that developmental changes of cardiac mitochondria, organelles responsible for calcium handling and energy production, are deeply involved in the regulation of cardiac tolerance to oxygen deprivation.

The explanation of the differences in cardiac tolerance to ischemia between newborn SHR and WKY is rather speculative since the data on cardiac tolerance during early postnatal development in these two strains are still lacking. For the elucidation of this problem, the fact that the heart of newborn SHR is enlarged as compared with WKY (Gray 1984), should be taken into consideration. We have observed increased hydration (the proportion of water content) of hearts in SHR. However, cardiac enlargement is predominantly due to hyperplasia of muscle cells, which is characteristic for cardiac growth during fetal and early postnatal period. Simultaneously, relative heart weight increases; it reaches the maximum values during the first postnatal week and afterwards slowly decreases till adulthood (Kuneš et al. 1997). The heart of newborn SHR thus consists of an increased number of smaller myocytes and an increased capillary/fiber ratio as compared with WKY (Clubb et al. 1987). The possibility of impaired blood supply, typical of the hypertrophied heart of adult SHR, may thus be excluded. It has been observed that the mitotic activity of myocytes decreases earlier in SHR than in normotensive WKY; the switch between predominantly hyperplastic and hypertrophic growth thus occurs earlier in SHR (Engelmann and Gerrity 1988). It is interesting to note that cardiac enlargement in SHR is present already before the development of hypertension, suggesting the genetic origin of this adaptive reaction (Zicha and Kuneš 1999). The newborn SHR differ from WKY not only in the cardiac tolerance to ischemia but also in some other parameters. The inotropic response to catecholamines was significantly higher on the first postnatal day (Tanaka et al. 1988). We have observed a higher sensitivity to inotropic effect of increasing $\mathrm{Ca}^{2+}$ concentration in SHR newborns and this difference disappeared during the later development. Similarly as in hearts from neonatal Wistar rats (Ošt’ádalová et al. 2002), the protective effect of ischemic preconditioning or adaptation to chronic hypoxia was absent in neonatal SHR and WKY hearts. These results suggest that we might be dealing with a more general biological phenomenon: the already high resistance of the cardiac muscle cannot be further increased by different protective mechanisms. A similar situation as in the immature 
mammalian heart can also be observed in highly tolerant hearts of poikilotherms (Gamperl et al. 2004) or in the myocardium of young females (Ošt'ádal et al. 2009).

As has been mentioned above, in contrast with the newborn SHR, hypertrophied adult heart of SHR was significantly less tolerant to acute ischemia/reperfusion injury as compared with normotensive controls (Belichard et al. 1988, Snoeckx et al. 1989, 1993, Itter et al. 2004, Bešík et al. 2007). The mechanism responsible for the decreased tolerance of the hypertrophied hearts to ischemia is likely to be a complex array of interactive events. During myocardial ischemia the hypertrophied hearts exhibit an accelerated loss of high-energy phosphates, greater accumulation of tissue lactate and hydrogen ions, earlier onset of ischemic conctracture, accelerated calcium overload during early reperfusion (Friehs and del Nido 2003), impaired sodium handling (Golden et al. 1994) and decreased NO availability. Moreover, during the development of cardiac hypertrophy, myocytes enlarge without concomittant increasing capillarization; the delivery of oxygen as well as other nutrients is thus limited (Batra and Rakušan
1992). The diminished microvascular supply is associated with the decline in contractility and with increased vulnerability to ischemia-reperfusion injury (Friehs and del Nido 2003).

In conclusion, we have found that the hearts of newborn SHR are more tolerant to ischemia/reperfusion injury as compared with the hearts of age-matched WKY; this parameter significantly decreased in both strains after birth, similarly as in Wistar rats. Since this situation is quite opposite to that in the hearts of adult SHR, which are significantly less tolerant to ischemia, it would be of interest to define in future the developmental period when this ontogenetic crossing-over of the cardiac resistance to oxygen deprivation in SHR occurs.

\section{Conflict of Interest}

There is no conflict of interest.

\section{Acknowledgements}

This study was supported by grant of MSMT $1 \mathrm{M} 0510$ and grant AV0Z 50110509.

\section{References}

BATRA S, RAKUŠAN K: Capillary network geometry during postnatal growth in rat hearts. Am J Physiol 262: H635H640, 1992.

BELICHARD P, PRUNEAU D, ROCHETTE L: Influence of spontaneous hypertension and cardiac hypertrophy on the severity of ischemic arrhytmias in the rat. Basic Res Cardiol 83: 560-566, 1988.

BEŠÍK J, SZARSZOI O, KUNEŠ J, NETUKA I, MALÝ J, KOLÁŘ F, PIRK J, OŠŤÁDAL B: Tolerance to acute ischemia in adult male and female spontaneously hypertensive rats. Physiol Res 56: 267-274, 2007.

CAVE AC: The protective effect of preconditioning on postischemic contractile dysfunction. In: Myocardial Preconditioning. CL WAINWRIGHT, JR PARRATT (eds), Landes, Austin, TX, 1996, pp 61-78.

CLUBB FJ, BELL PD, KRISEMAN JD, BISHOP SP: Myocardial cell growth and blood pressure development in neonatal spontaneously hypertensive rats. Lab Invest 56: 189-197, 1987.

DI LISA F, BERNARDI P: Mitochondrial function as a determinant of recovery or death in cell response to injury. Mol Cell Biochem 184: 379-391, 1998.

DI LISA F, BERNARDI P: Mitochondrial function and myocardial aging. A critical analysis of the role of permeability transition. Cardiovasc Res 66: 222-232, 2005.

DICKHOUT JG, LEE RM: Blood pressure and heart rate development in young spontaneously hypertensive rats. $A m J$ Physiol 274: H794-H800, 1998.

ENGELMANN GL, GERRITY RG: Biochemical characterization of neonatal cardiomyocyte development in normotensive and hypertensive rats. J Mol Cell Cardiol 20: 169-177, 1988.

FEJFAR Z: Prevention against ischemic heart disease: a critical review. In: Modern Trends in Cardiology. MF OLIVER (ed), Butterworth-Heinemann, Boston, MA, 1975, pp 465-499.

FRIEHS I, DEL NIDO PJ: Increased susceptibility of hypertrophied hearts to ischemic injury. Ann Thorac Surg 75: S678-S684, 2003.

GAMPERL AK, FAUST HA, DOUGHER B, RODNICK KJ: Hypoxia tolerance and preconditioning are not additive in the trout (Oncorhynchus mykiss) heart. J Exp Biol 207: 2497-2505, 2004. 
GOLDEN AL, BRIGHT JM, POHOST GM, PIKE MM: Ischemic dysfunction and impaired recovery in hypertensive hypertrophied hearts is associated with exaggerated intracellular sodium accumulation. Am J Hypertens 7: 745754, 1994.

GRAY SD: Pressure profiles in neonatal spontaneously hypertensive rats. Biol Neonate 45: 25-32, 1984.

HOERTER J: Change in the sensitivity to hypoxia and glucose deprivation in the isolated perfused rabbit heart during perinatal development. Pflügers Arch 363: 1-6, 1976.

ITTER G, JUNG W, JURETSCHKE P, SCHOELKENS BA, LINZ W: A model of chronic heart failure in spontaneous hypertensive rats (SHR). Lab Anim 38: 138-148, 2004.

JULIA P, YOUNG PP, BUCKBERG GD, KOFSKY ER, BUGYI HI: Studies of myocardial protection in the immature heart. II. Evidence for importance of amino acid metabolism in tolerance to ischemia. J Thorac Cardiovasc Surg 100: 888-895, 1990.

KUNEŠ J, DOBEŠOVÁ Z, ZICHA J: Cardiac hypertrophy in newborn rats with genetic or experimental hypertension. In: The Developing Heart. B OŠŤÁDAL, M NAGANO, N TAKEDA, NS DHALLA (eds), Lippincott, Philadelphia, PA, 1997, pp 337-346.

MILL JG, NOVAES MA, GALON M, NOGUEIRA JB, VASSALLO DV: Comparison of the contractile performance of the hypertrophied myocardium from spontaneous hypertensive rats and normotensive infarcted rats. Can $J$ Physiol Pharmacol 76: 387-394, 1998.

MILEROVÁ M, CHARVÁTOVÁ Z, ŠKÁRKA L, OŠŤÁDALOVÁ I, DRAHOTA Z, FIALOVÁ M, OŠŤÁDAL B: Neonatal cardiac mitochondria and ischemia/reperfusion injury. Mol Cell Biochem 335: 147-153, 2010.

MORTOLA JP: Implications of hypoxic hypometabolism during mammalian ontogenesis. Respir Physiol Neurobiol 141: 345-356, 2004.

NIJJAR MS, DHALLA NS: Biochemical basis of calcium handling in developing myocardium. In: The Developing Heart. B OŠŤÁDAL, M NAGANO, N TAKEDA, NS DHALLA (eds), Lippincott, Philadelphia, PA, 1997, pp 189-217.

OŠŤÁDAL B, OŠŤÁDALOVÁ I, DHALLA NS: Development of cardiac sensitivity to oxygen deficiency: comparative and ontogenetic aspects. Physiol Rev 79: 635-659, 1999.

OŠŤÁDAL B, CHARVÁTOVÁ Z, OŠŤÁDALOVÁ I, KOLÁŘ F, NETUKA I: Development of myocardial tolerance to oxygen deficiency - experimental aspects. Cor Vasa 51: 691-697, 2009.

OŠŤÁDALOVÁ I, KOLÁŘ F, OŠŤÁDAL B, ROHLÍČEK V, ROHLÍČEK J, PROCHÁZKA J: Early postnatal development of contractile performance and responsiveness to $\mathrm{Ca}^{2+}$, verapamil and ryanodine in the isolated rat heart. J Mol Cell Cardiol 25: 733-740, 1993.

OŠŤÁDALOVÁ I, KOLÁŘ F, OŠŤÁDAL B, PARRATT JR: Ischaemic preconditioning in neonatal rat heart. $J$ Physiol Lond 491: 6P-7P, 1996.

OŠŤÁDALOVÁ I, OŠŤÁDAL B, KOLÁ̌̌ F, PARRAT JR, WILSON S: Tolerance to ischaemia and ischaemic preconditioning in neonatal rat heart. J Mol Cell Cardiol 30: 857-865, 1998.

OŠŤÁDALOVÁ I, OŠŤÁDAL B, JARKOVSKÁ D, KOLÁŘ F: Ischemic preconditioning in chronically hypoxic neonatal rat heart. Pediatr Res 52: 561-567, 2002.

RIVA E, HEARSE DJ: Age-dependent changes in myocardial succeptibility to ischemic injury. Cardioscience 4: 8592, 1993.

SINGER D: Metabolic adaptation to hypoxia: cost and benefit of being small. Respir Physiol Neurobiol 141: 215-228, 2004.

SNOECKX LH, VAN DER VUSSE GJ, VAN DER VEEN FH, COUMANS WA, RENEMAN R: Recovery of hypertrophied rat hearts after global ischemia and reperfusion at different perfusion pressures. Pflugers Arch 413: 303-312, 1989.

SNOECKX LH, VAN DER VUSSE GJ, COUMANS WA, WILLEMSEN PH, RENEMAN R: Differences in ischaemia tolerance between hypertrophied hearts of adult and aged spontaneously hypertensive rats. Cardiovasc Res 27: 874-881, 1993.

SOUTHWORTH R, SHATTOCK MJ, KELLY FJ: Age-related difference in the cardiac response to ischemia and free radical production on reperfusion. In: The Developing Heart. B OŠŤÁDAL, M NAGANO, N TAKEDA, NS DHALLA (eds), Lippincott, Philadelphia, PA, 1997, pp 427-441. 
ŠKÁRKA L, BARDOVÁ K, BRAUNER P, FLACHS P, JARKOVSKÁ D, KOPECKÝ J, OŠŤÁDAL B: Expression of mitochondrial uncoupling protein 3 and adenine nucleotide translocase 1 genes in developing rat heart: putative involvement in control of mitochondrial membrane potential. J Mol Cell Cardiol 35: 321-330, 2003.

TANAKA H, KASUYA Y, SHIGENOBU K: Altered responsiveness to autonomic transmitters of hearts from neonatal spontaneously hypertensive rats. J Cardiovasc Pharmacol 12: 678-682, 1988.

YOUNG HH, SHIMIZU T, NISHIOKA K, NAKANISHI T, JARMAKANI JM: Effect of hypoxia and reoxygenation on mitochondrial function in neonatal myocardium. Am J Physiol 245: H998-H1006, 1983.

ZICHA J, KUNEŠ J: Ontogenetic aspects of hypertension development: analysis in the rat. Physiol Rev 79: 1227-1282, 1999. 